ISSN: 1858-4837; E-ISSN: 2598-019X

Volume 16, Nomor 2 (2021),

https://jurnal.uns.ac.id/region

DOI: 10.20961/region.v16i2.32968

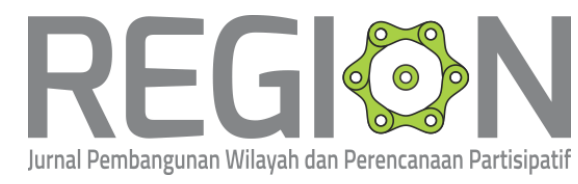

\title{
Pengaruh dana desa terhadap pertumbuhan ekonomi dan kemiskinan di Sumatera Barat
}

\author{
The effect of village funds on economic growth and poverty in West Sumatera
}

\author{
A Ritonga ${ }^{1}$, H Handra $^{1}$, dan F Andrianus ${ }^{1}$ \\ ${ }^{1}$ Perencanaan Pembangunan, Fakultas Ekonomi, Universitas Andalas
}

Corresponding author's email: andyritonga@ymail.com

\begin{abstract}
Abstrak. Penelitian ini bertujuan melihat pengaruh dana desa terhadap pertumbuhan dan kemiskinan kabupaten dan kota di Sumatera Barat. Analisis pengaruh dana desa dilakukan menggunakan data panel pada kabupaten dan kota dalam kurun waktu 2015 sampai 2018. Di samping variabel dana desa digunakan pula variabel jumlah pengangguran, rata-rata upah, dan angkatan kerja sebagai variabel penjelas. Hasil penelitian menunjukkan bahwa terdapat pengaruh negatif dana desa terhadap pertumbuhan dan terhadap kemiskinan serta memiliki hubungan yang signifikan. Pengaruh tersebut pada kurun waktu penelitian terbilang tidak besar terhadap kemiskinan, serta dianggap tidak efektif untuk meningkatkan pertumbuhan ekonomi kabupaten dan kota di Sumatera Barat. Begitu pula dengan variabel penjelas, variabel jumlah pengangguran, rata-rata upah, dan angkatan kerja memiliki pengaruh negatif terhadap pertumbuhan dan tidak memiliki hubungan yang signifikan serta variabel jumlah pengangguran dan angkatan kerja memiliki hubungan signifikan terhadap kemiskinan dan berpengaruh negatif.
\end{abstract}

Kata Kunci: Dana Desa; Data Panel; Kemiskinan; Pertumbuhan Ekonomi

\begin{abstract}
This study aims to investigate the effect of village fund on the economic growth and poverty of districts and cities in West Sumatra. The analysis of the effect of village fund employed panel data on districts and cities in the period of 2015 to 2018. Besides the village fund variable, the research used the unemployment, average wages, and labour force as explanatory variables. The results of the study showed that there was a negative influence of village fund on economic growth and poverty and had a significant relationship. The effect on poverty in the research period is relatively
\end{abstract}

Received: July 29, 2019; Accepted: June 26, 2020; Available online: July 15, 2021

Copyright $\odot$ 2021, REGION: Jurnal Pembangunan Wilayah dan Perencanaan Partisipatif 
small and is considered ineffective to increase economic growth in the districts and cities in West Sumatra. Likewise with explanatory variables, the unemployment, average wages, and labour force has a negative effect on economic growth and does not have a significant relationship. Meanwhile, the unemployment and labour force variable has a significant relationship with poverty and has a negative effect.

Keywords: Economic Growth; Panel Data; Poverty; Village Fund

\section{Pendahuluan}

Indonesia telah melakukan desentralisasi hingga ke tingkat desa. Desentralisasi hingga ke desa tersebut bertujuan untuk mendekatkan pelayanan dasar terhadap masyarakat desa, menurunkan kemiskinan dan memperkecil ketimpangan. Hal tersebut menunjukkan keyakinan pemerintah bahwa pembangunan berbasis perdesaan dapat memperkuat pondasi perekonomian, menurunkan kemiskinan, dan memperkecil ketimpangan antar wilayah. Walaupun untuk mencapai tujuan pembangunan tersebut, menurut Sjafrizal [1], membutuhkan pemetaan atas kebutuhan masing-masing daerah, integritas, sinergitas, dan sinkronisasi dari masing-masing pemegang kepentingan.

Pembangunan perdesaan saat ini memerlukan pelaksana multi aktor dalam multi tingkatan kehidupan dalam tujuannya memecahkan multi persoalan yang mengemuka yang berakar pada tradisi sejarah kedaerahan [2]. Perdesaan diciptakan menjadi tempat yang menarik untuk tempat tinggal dan tempat berusaha, sehingga saat ini desa bukan lagi hanya milik petani.

Untuk mendukung pembangunan perdesaan dan sesuai amanat Peraturan Pemerintah nomor 60 tahun 2014, pemerintah mengalokasikan belanja dana desa dalam Anggaran Pendapatan dan Belanja Negara (APBN). Dana desa sebagai salah satu pengeluaran pemerintah telah direalisasi sejak tahun 2015. Sejak tahun 2015 anggaran dana desa selalu mengalami peningkatan dengan tingkat penyerapan anggaran yang cukup tinggi. Dari awal pengucurannya, daerah dengan jumlah desa paling banyak selalu menerima alokasi dana paling besar. Sedangkan kemiskinan tersebar hampir merata di seluruh kabupaten kota di Sumatera Barat bahkan Indonesia. Pengalokasian dana desa ini masih dianggap banyak pihak belum sesuai dengan tujuannya. Seperti halnya Lewis [3] yang menganggap bahwa masih kurang tepat apabila dana desa dialokasikan seperti formula saat ini, sedangkan heterogenitas antar wilayah perdesaan sangat signifikan.

Regulasi mengamanatkan dana desa dianggarkan melalui Angggaran Pendapatan dan Belanja Negara dengan memperhatikan jumlah penduduk, angka kemiskinan, luas wilayah, dan tingkat kesulitan geografis. Secara garis besar, tujuan kebijakan dana desa tersebut adalah memberikan kesejahteraan bagi masyarakat desa dan memperkecil kesenjangan antar wilayah. Dalam hal ini, Daforsa \& Handra [4] telah membuktikan adanya dampak dana desa terhadap pengurangan kemiskinan di Kabupaten Pasaman. Dampak dana desa tersebut tidak terlalu besar terhadap pengurangan kemiskinan karena masih dilakukan dalam tiga tahun serta perlu ada keseimbangan anggaran pembangunan infrastruktur dan pembangunan 
sumber daya manusia. Begitu pula penelitian Tangkumahat et al [5] yang menunjukkan hasil bahwa program dana desa berdampak positif terhadap peningkatan pembangunan dan perekonomian masyarakat di Kecamatan Pineleng, Kabupaten Minahasa.

Prioritas penggunaan dana desa untuk bidang pembangunan desa ditujukan untuk pembangunan sarana prasarana dasar, sarana prasarana pelayanan sosial dasar, mewujudkan lumbung ekonomi desa, dan sarana prasarana lingkungan. Sedangkan bidang pemberdayaan masyarakat diprioritaskan untuk meningkatkan kapasitas dan kapabilitas masyarakat desa dengan mendayagunakan potensi dan sumber dayanya.

Beberapa penelitian lain juga telah membuktikan bahwa pengeluaran pemerintah yang merupakan komponen kebijakan fiskal dapat meningkatkan pertumbuhan ekonomi dan menurunkan kemiskinan. Di antara pengeluaran pemerintah yang besar pengaruhnya dan signifikan mempengaruhi kemiskinan dan pertumbuhan di wilayah perdesaan adalah di bidang infrastruktur jalan, irigasi, dan dukungan di bidang pertanian. Seperti yang dikemukakan Fan et al [6] pada penelitiannya di India dengan menggunakan model persamaan simultan. Untuk meningkatkan pertumbuhan ekonomi perdesaan, Pemerintah harus memprioritaskan investasi di bidang infrastruktur jalan yang menghubungkan antar perdesaan dan ke perkotaan serta peningkatan penelitian di bidang pertanian. Antwi et al [7] mengemukakan bahwa dalam jangka panjang faktor-faktor ekonomi makro seperti pengeluaran pemerintah, investasi swasta, dan tenaga kerja sangat efektif meningkatkan pertumbuhan ekonomi di Ghana. Namun, faktor tenaga kerja tidak efektif meningkatkan pertumbuhan ekonomi dalam jangka pendek.

Provinsi Sumatera Barat memiliki 12 kabupaten dan 7 kota, dimana 12 kabupaten dan 2 kota di antaranya memperoleh anggaran dana desa. Namun, untuk masing-masing daerah terdapat perbedaan jumlah desa yang sangat signifikan. Antara lain seperti Kabupaten Pasaman Barat hanya memiliki 19 desa (nagari), sedangkan Kabupaten Pesisir Selatan memiliki 182 desa. Kondisi ini mengakibatkan perbedaan yang signifikan terhadap penerimaan dana desa untuk masing-masing daerah.

Total desa di Provinsi Sumatera Barat yaitu sejumlah 928 desa seperti ditunjukkan pada Gambar 1. Dimana 100 desa di antaranya merupakan desa tertinggal dan desa sangat tertinggal menurut data Kementrian Desa PDTT (2017). Jika dilihat dari data tahun 2015 dan 2017 terjadi penurunan jumlah desa tertinggal dan desa sangat tertinggal di seluruh kabupaten dan kota penerima dana desa Sumatera Barat. Peningkatan status desa tersebut sangat didukung oleh peningkatan sarana prasarana di wilayah perdesaan dan kualitas sumber daya desa. 


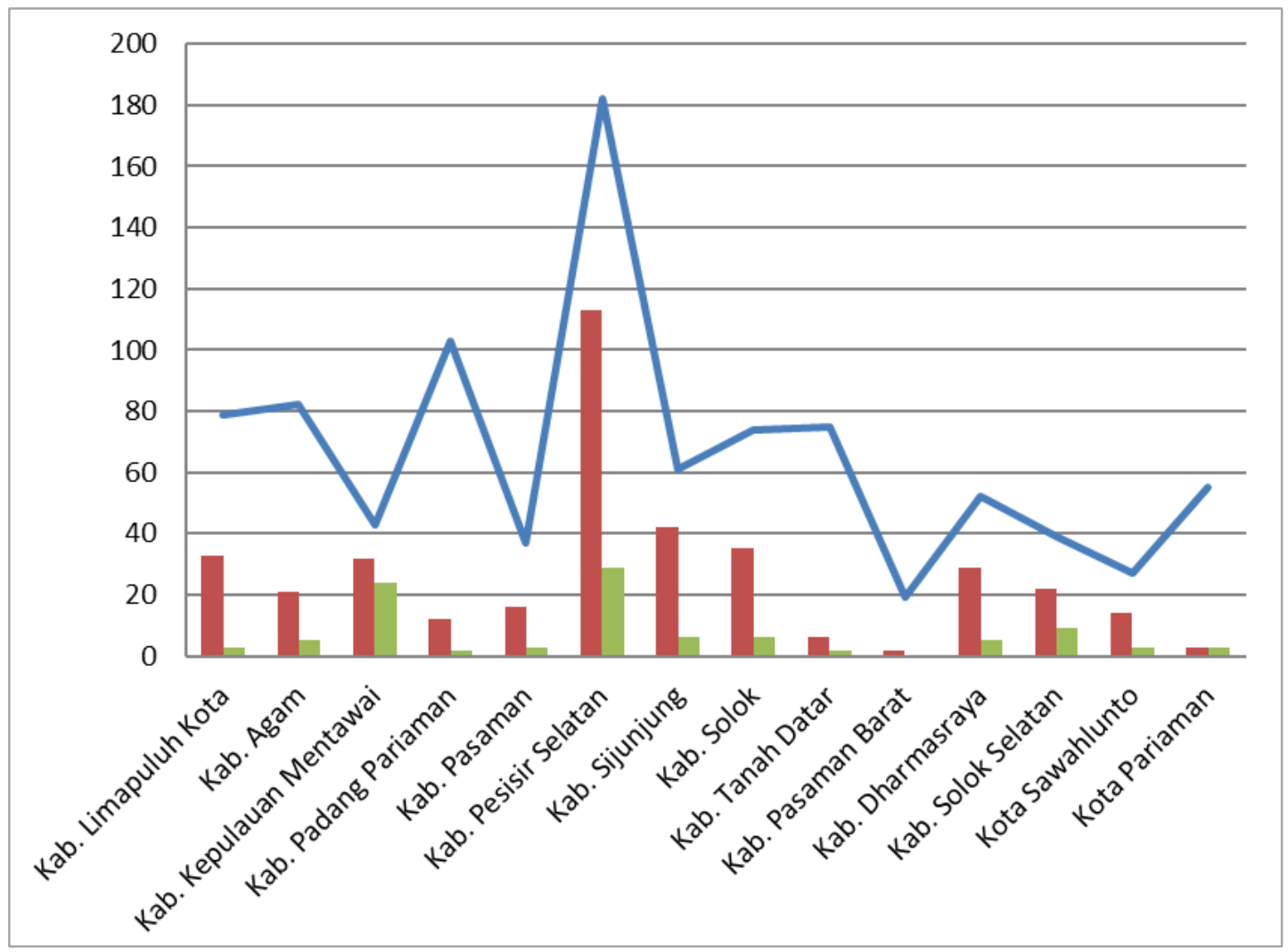

Gambar 1. Grafik jumlah desa, jumlah desa tertinggal dan desa sangat tertinggal Provinsi Sumatera Barat tahun 2015 dan 2017 [8]

Tingkat pendidikan masyarakat Sumatera Barat mayoritas hanya menamatkan sekolah lanjutan tingkat pertama sebesar $65,98 \%$, sedangkan yang mampu menamatkan pendidikan tinggi hanya sebesar 8,53\% [9]. Faktor ini mempengaruhi angkatan kerja dan tingkat pengangguran, di mana jumlah pengangguran terbesar merupakan tamatan sekolah lanjutan atas. Sehingga banyak pengeluaran Pemerintah Provinsi Sumatera Barat dialokasikan untuk bidang pendidikan, yang pada beberapa penelitian menunjukkan hasil yang signifikan mempengaruhi pertumbuhan dan kemiskinan [10]. Jika dilihat antara kabupaten dan kota, rata-rata tingkat pengangguran kota lebih tinggi dibandingkan dengan kabupaten. Namun, PDRB perkapita kota pada umumnya lebih tinggi dibandingkan dengan kabupaten [9]. Kondisi ini menunjukkan bahwa masyarakat perkotaan di Sumatera Barat lebih sejahtera dibandingkan masyarkat perdesaannya.

Pembahasan tentang kemiskinan telah membawa perkembangan pendapat tentang determinan kemiskinan itu sendiri. Menurut World Bank, salah satu penyebab kemiskinan adalah kurangnya pendapatan dan aset untuk memenuhi kebutuhan dasar. Di mana World Bank telah menetapkan standar kemiskinan berdasarkan pendapatan perkapita yaitu USD \$2 per hari. Kondisi kemiskinan menurut Nurkse [11] dapat dipecahkan dengan memberikan stimulus dengan strategi dorongan besar dalam pertumbuhan ekonomi yang seimbang. 
Dorongan besar yang dimaksud berupa investasi besar, salah satunya berasal dari pengeluaran pemerintah.

Kemiskinan di Sumatera Barat untuk lima tahun terakhir masih terbilang rendah jika dilihat dari rata-rata nasional. Namun, angka kemiskinan perdesaan selalu lebih tinggi dibandingkan perkotaan. Untuk periode September tahun 2018, jumlah penduduk miskin perkotaan adalah sebanyak 125,58 ribu jiwa atau 5,11\% sedangkan perdesaan sebanyak 245,41 ribu jiwa atau 7,98\% [9]. Dalam menyikapi kondisi ini, Pemerintah Provinsi Sumatera Barat memerlukan kebijakan yang dapat menciptakan pemerataan antar daerah atau wilayah, terutama pemerataan antara daerah perkotaan dan perdesaan.

Laju pertumbuhan ekonomi Provinsi Sumatera Barat dalam kurun waktu 2015-2018 selalu melambat dengan rata-rata pertumbuhan sebesar $5.30 \%$. Kondisi laju pertumbuhan yang melambat dipengaruhi oleh sektor pertanian, yang menjadi primadona, menunjukkan pertumbuhan yang melambat. Sedangkan sektor yang sedang tumbuh seperti sektor informasi dan komunikasi serta sektor penyediaan akomodasi dan makan minum belum dapat mendongkrak pertumbuhan ekonomi Sumatera Barat [9].

Dalam kondisi pertumbuhan ekonomi yang selalu melemah pada kurun waktu penelitian, anggaran dana desa ini selalu ditingkatkan. Di sisi lain, tingkat kemiskinan menurun dalam hitungan yang kecil. Penelitian ini menggunakan data 12 kabupaten dan 2 kota penerima dana desa di Sumatera Barat dalam kurun waktu 2015 hingga 2018. Penelitian ini dilakukan untuk mengetahui sejauh mana pengaruh kebijakan dana desa terhadap pertumbuhan ekonomi dan kemiskinan di Provinsi Sumatera Barat, terutama untuk daerah-daerah yang memiliki wilayah perdesaan.

\section{Metode}

Penelitian ini akan dipaparkan secara deskriptif dan analisis kuantitatif dengan menggunakan data sekunder tahun 2015 hingga tahun 2018. Data sekunder yang digunakan berbentuk data panel dari 14 kabupaten dan kota di Sumatera Barat yang menerima dana desa. Sumber data yang digunakan berasal dari publikasi data sebagai berikut: (1) data dana desa berasal dari publikasi Kementerian Keuangan dan (2) data penduduk miskin, PDRB, dan data lain yang digunakan sebagai variabel penjelas yaitu tingkat pengangguran terbuka, rata-rata upah buruh atau karyawan dan jumlah angkatan kerja dari publikasi Badan Pusat Statistik. Sedangkan dalam pengolahan data regresinya dilakukan melalui bantuan aplikasi stata.

Untuk menjawab tujuan penelitian ini dalam melihat dampak dana desa terhadap pertumbuhan ekonomi dan kemiskinan di Sumatera Barat, diperlukan beberapa variabel penjelas. Variabel kuantitatif yang digunakan berdasarkan teori ekonomi makro klasik, neoklasik dan teori pertumbuhan baru, dengan dua rancangan model penelitian. Model pertama (I) digunakan untuk melihat dampak dana desa terhadap pertumbuhan ekonomi.

$$
P t_{i t}=\beta_{0}+\beta_{1} D D_{i t}+\beta_{2} P_{i t}+\beta_{3} U_{i t}+\beta_{4} A K_{i t}+e_{i t}
$$


Model kedua (II) digunakan untuk menjelaskan dampak dana desa terhadap tingkat kemiskinan di Sumatera Barat.

$$
K_{i t}=\beta_{5}+\beta_{6} D D_{i t}+\beta_{7} P_{i t}+\beta_{8} U_{i t}+\beta_{9} A K_{i t}+e_{i t}
$$

Di mana variabel terikat terdiri dari $K$ yang merupakan persentase penduduk miskin kabupaten kota, dan Pt yang merupakan tingkat pertumbuhan ekonomi. Untuk variabel bebas terdiri dari DD, yaitu jumlah dana desa kabupaten kota dalam rupiah, $\mathrm{P}$ merupakan tingkat pengangguran terbuka yang diukur dalam persen, $U$ adalah rata-rata upah buruh atau karyawan dalam setahun yang diukur dalam rupiah dan AK merupakan variabel jumlah angkatan kerja. Sedangkan $e$ merupakan error term dan $\beta$ merupakan koefisien regresi.

\section{Hasil penelitian dan pembahasan}

Estimasi pertama penelitian ini adalah untuk melihat dampak dana desa terhadap pertumbuhan ekonomi Sumatera Barat. Pemilihan model pertama sebagaimana yang ditunjukkan persamaan (1) akan diuji menggunakan uji Chow untuk melihat konsistensi pendugaan dengan fixed effect. Pengujian Chow untuk menentukan penggunaan model fixed effect atau pooled/OLS. Hasil menunjukkan nilai probability dari F statistik (Prob $>$ F) $<$ nilai $\alpha$ $=0.05$ yaitu 0.000 atau bernilai signifikan. Sehingga dari hasil tersebut ditarik kesimpulan bahwa model fixed effect baik digunakan.

Setelah uji Chow, langkah selanjutnya dilakukan uji Hausman untuk menentukan model terbaik antara fixed effect dengan random effect. Hasil uji Hausman menunjukkan bahwa nilai probability (Prob > Chi2) < nilai $\alpha$ yaitu 0.0012. Dari hasil tersebut diputuskan model terbaik yang dapat digunakan adalah fixed effect.

Tabel 1. Hasil regresi dengan fixed effect persamaan (1).

\begin{tabular}{rcccccc}
\hline Pt & Coef & Std. Err. & $\mathrm{t}$ & $\mathrm{P}>|\mathrm{t}|$ & \multicolumn{2}{c}{ [95\% Conf. Interval] } \\
\hline DD & $-6.19 \mathrm{e}-14$ & $1.58 \mathrm{e}-14$ & -3.92 & 0.000 & $-9.38 \mathrm{e}-14$ & $-2.99 \mathrm{e}-14$ \\
$\mathrm{P}$ & -.0330746 & .022583 & -1.46 & 0.151 & -.0787916 & .0126423 \\
$\mathrm{U}$ & $-5.77 \mathrm{e}-11$ & $5.76 \mathrm{e}-11$ & -1.00 & 0.323 & $-1.74 \mathrm{e}-10$ & $5.90 \mathrm{e}-11$ \\
AK & $-1.14 \mathrm{e}-08$ & $4.78 \mathrm{e}-08$ & -0.24 & 0.812 & $-1.08 \mathrm{e}-07$ & $-8.53 \mathrm{e}-08$ \\
_cons & .0612403 & .0061313 & 9.99 & 0.000 & .0488282 & .0736524 \\
\hline
\end{tabular}

Sigma_u .00333958

Sigma_e 00118355

rho. $\quad 88781966$ (fraction of variance due to $u_{-} i$ )

F test that all $u_{-} i=0: F(13,38)=11,86 \quad$ Prob $>F=0.0000$

Hasil estimasi dengan model terbaik fixed effect seperti yang ditunjukkan oleh Tabel 1 bahwa terdapat hanya satu variabel independen yang signifikan pada taraf $5 \%$ dan mempengaruhi variabel pertumbuhan secara parsial yaitu variabel dana desa dengan $(P>|t|)=0,000$. 
Sedangkan terdapat tiga variabel independen lainnya tidak signifikan, yaitu variabel pengangguran, upah dan angkatan kerja. Hasil regresi pada Tabel 1 menunjukkan bahwa ke empat variabel independen memiliki hubungan negatif dengan variabel pertumbuhan.

Tabel 2. Hasil uji multikolinearitas.

\begin{tabular}{ccc}
\hline Variabel & VIF & 1/VIF \\
\hline U & 9.38 & 0.106592 \\
P & 7.20 & 0.138954 \\
AK & 6.18 & 0.161752 \\
DD & 4.77 & 0.209812 \\
Mean VIF & 6.88 & \\
\hline
\end{tabular}

Setelah menentukan model estimasi yang tepat, dilanjutkan dengan melakukan uji asumsi klasik. Uji asumsi yang dilakukan adalah asumsi multikolinearitas dengan hasil seperti ditunjukkan pada Tabel 2. Uji asumsi multikolinearitas ini dilakukan untuk melihat hubungan antar variabel bebas pada setiap model. Nilai yang ditunjukkan tabel 2 adalah mean VIF $<10$ atau nilai tolerance $(1 / \mathrm{VIF})>0.1$, nilai ini menandakan tidak terdapat gejala multikolinearitas pada model.

Kemudian, berdasarkan hasil regresi dapat dilihat hubungan signifikansi serentak antara variabel pada persamaan/model. Uji signifikansi serentak atau uji F dilihat dari nilai (Prob>Chi2) $=0.000$ berarti (Prob $>$ Chi2) $<\alpha(0.05)$, dengan demikian $\mathrm{H} 1$ diterima. Hal ini berarti variabel independen dana desa, pengangguran, upah dan angkatan kerja secara bersama-sama atau salah satunya signifikan mempengaruhi variabel dependen pertumbuhan pada taraf kepercayaan $95 \%$.

Setelah mengolah data regresi persamaan (1), dilanjutkan meregresi persamaan (2) untuk menganalisis dampak dana desa terhadap tingkat kemiskinan Sumatera Barat. Pemilihan model terbaik diawali uji Chow dimana hasil uji Chow menunjukkan nilai probability dari $\mathrm{F}$ statistik (Prob $>$ F) $<$ nilai $\alpha=0.05$ yaitu 0.000 atau signifikan. Sehingga dari hasil uji Chow tersebut ditarik kesimpulan model lebih baik digunakan adalah fixed effect.

Setelah itu dilakukan uji Hausman, untuk melihat model terbaik antara fixed effect atau random effect. Dari uji Hausman hasil menunjukkan nilai probability (Prob $>C h i 2)=-0.30$. Hasil ini tidak dapat membuktikan untuk menerima $\mathrm{HO}$ yang disebabkan adanya asumsi yang tidak terpenuhi pada saat melakukan uji Hausman karena hasilnya menunjukkan nilai negatif. Maka dari kedua uji yang dilakukan diputuskan model terbaik yang dapat digunakan adalah fixed effect. 
Tabel 3. Hasil regresi dengan fixed effect persamaan (2).

\begin{tabular}{rcccccc}
\hline $\mathrm{K}$ & Coef & Std. Err. & $\mathrm{t}$ & $\mathrm{P}>|\mathrm{t}|$ & \multicolumn{2}{c}{ [95\% Conf. Interval] } \\
\hline DD & $-9.01 \mathrm{e}-14$ & $2.74 \mathrm{e}-14$ & -3.29 & 0.002 & $-1.46 \mathrm{e}-13$ & $-3.47 \mathrm{e}-14$ \\
$\mathrm{P}$ & -.1315727 & .0391634 & -3.36 & 0.002 & -.2108549 & -.0522904 \\
$\mathrm{U}$ & $-1.23 \mathrm{e}-10$ & $9.99 \mathrm{e}-11$ & -1.23 & 0.226 & $-3.25 \mathrm{e}-10$ & $7.93 \mathrm{e}-11$ \\
AK & $-1.95 \mathrm{e}-07$ & $8.29 \mathrm{e}-08$ & -2.35 & 0.024 & $-3.62 \mathrm{e}-07$ & $-2.67 \mathrm{e}-08$ \\
_cons & .1147069 & .0106328 & 10.79 & 0.000 & .0931818 & .1362319 \\
\hline
\end{tabular}

Sigma_u .03102222

Sigma_e $\quad 0020525$

rho. 99564162 (fraction of variance due to $u_{-} i$ )

F test that all u_i $=0: F(13,38)=439.79$

Prob $>\mathrm{F}=0.0000$

Estimasi dengan fixed effect pada Tabel 3 menunjukkan bahwa terdapat tiga variabel independen yang signifikan pada taraf $5 \%((P>|t|)<\alpha)$ mempengaruhi variabel kemiskinan, yaitu variabel dana desa, pengangguran dan angkatan kerja. Kemudian terdapat satu variabel independen yang tidak signifikan mempengaruhi variabel kemiskinan, yaitu variabel upah. Hasil estimasi menunjukkan ke empat variabel independen memiliki hubungan negatif dengan variabel kemiskinan.

Setelah menentukan model estimasi yang paling tepat, dilanjutkan dengan melakukan uji asumsi klasik. Uji asumsi yang dilakukan adalah asumsi multikolinearitas dengan hasil sama dengan Tabel 2 (sama dengan persamaan (1)). Nilai pada Tabel 2 menunjukkan bahwa nilai mean VIF $<10$ atau nilai tolerance $(1 / \mathrm{VIF})>0.1$, nilai tersebut menunjukkan tidak terdapat gejala multikolinearitas pada persamaan.

Kemudian berdasarkan hasil regresi dapat dilihat hubungan signifikansi serentak antara variabel pada persamaan. Uji signifikansi serentak atau uji F dilihat dari nilai (Prob $>F)=0.000$ berarti (Prob > F) < $\alpha(0.05)$, dengan demikian H1 diterima. Kondisi ini berarti variabel independen dana desa, pengangguran, upah dan angkatan kerja secara bersama-sama sebagian atau seluruhnya signifikan mempengaruhi variabel dependen kemiskinan pada taraf kepercayaan $95 \%$.

\subsection{Gambaran kemiskinan dan dana desa di Sumatera Barat}

Kabupaten dan kota di Sumatera Barat memiliki variasi jumlah desa (nagari) yang sangat signifikan. Terdapat kabupaten dengan jumlah desa yang banyak, hal ini menjadikan kabupaten tersebut memperoleh distribusi dana desa yang relatif besar seperti Kabupaten Pesisir Selatan, Lima Puluh Kota dan Kabupaten Solok. Sedangkan di sisi lain terdapat pula kabupaten dan kota dengan jumlah desa sedikit seperti Kabupaten Pasaman Barat yang memiliki 19 desa atau Kota Sawahlunto yang memiliki 27 desa. Daerah dengan jumlah desa 
kecil ini tentunya akan memperoleh distribusi dana desa yang relatif kecil. Hal tersebut menurut Lewis [3] disebabkan metode pengalokasian dana desa yang diterapkan belum sesuai dengan tujuan dana desa itu sendiri. Sebagian besar alokasi ditetapkan berdasarkan perhitungan bagi rata, belum memperhatikan kebutuhan desa dalam meningkatkan kondisi desa serta kemampuan fiskal desa tersebut.

Pada periode 2015-2018, persentase kemiskinan Sumatera Barat masih terbilang rendah dan cenderung menurun. Namun, jika dilihat per kabupaten kota penerima dana desa, terdapat beberapa kabupaten yang memiliki tingkat kemiskinan di atas rata-rata kemiskinan provinsi. Di sisi lain, umumnya daerah perkotaan memiliki tingkat kemiskinan yang rendah dan tingkat pertumbuhan yang tinggi, seperti Kota Sawahlunto pada periode penelitian yang rata-rata tingkat kemiskinannya berada pada tingkat $2,20 \%$, sedangkan rata-rata pertumbuhan sekitar $5,76 \%$.

Gambar 2 menunjukkan pengelompokan daerah berdasarkan jumlah penerimaan dana desa dan tingkat kemiskinannya. Kriteria kemiskinan yang diolah menggunakan angka kemiskinan Provinsi Sumatera Barat sebagai pedoman. Apabila angka kemiskinan kabupaten atau kota berada di atas angka kemiskinan provinsi, maka dikategorikan pada kemiskinan tinggi, atau sebaliknya. Sedangkan untuk kriteria dana desa menggunakan nilai rata-rata kabupaten dan kota. Apabila dana desa kabupaten atau kota berada di atas rata-rata kabupaten dan kota, maka dikategorikan dana desa tinggi, begitu pula sebaliknya.

Berdasarkan Gambar 2 dapat dilihat bahwa pada periode 2015-2018 terdapat daerah yang persentase kemiskinannya menurun di bawah rata-rata provinsi yaitu Kabupaten Agam dan Dharmasraya. Walaupun secara rata-rata distribusi penerimaan dana desa kedua daerah berada pada kelompok yang berbeda. Kabupaten Agam memperoleh alokasi dana desa lebih besar dibandingkan Kabupaten Dharmasraya. Jika dilihat dari penurunan tingkat kemiskinan dari tahun 2015, Kabupaten Agam selalu memiliki angka penurunan tingkat kemiskinan yang lebih besar dari Kabupaten Dharmasraya. Sedangkan sembilan daerah lain tingkat kemiskinannya masih berada di atas rata-rata provinsi hingga tahun 2018 [12].

Di sisi lain, berdasarkan data BPS [9], perekonomian Sumatera Barat dalam periode waktu penelitian mengalami perlambatan pertumbuhan setiap tahunnya. Kondisi ini diikuti oleh mayoritas daerah-daerah kabupaten dan kota di Sumatera Barat. Sektor lapangan usaha pertanian, kehutanan dan perikanan yang menjadi sektor primadona perekonomian Sumatera Barat belum dapat tumbuh maksimal. 

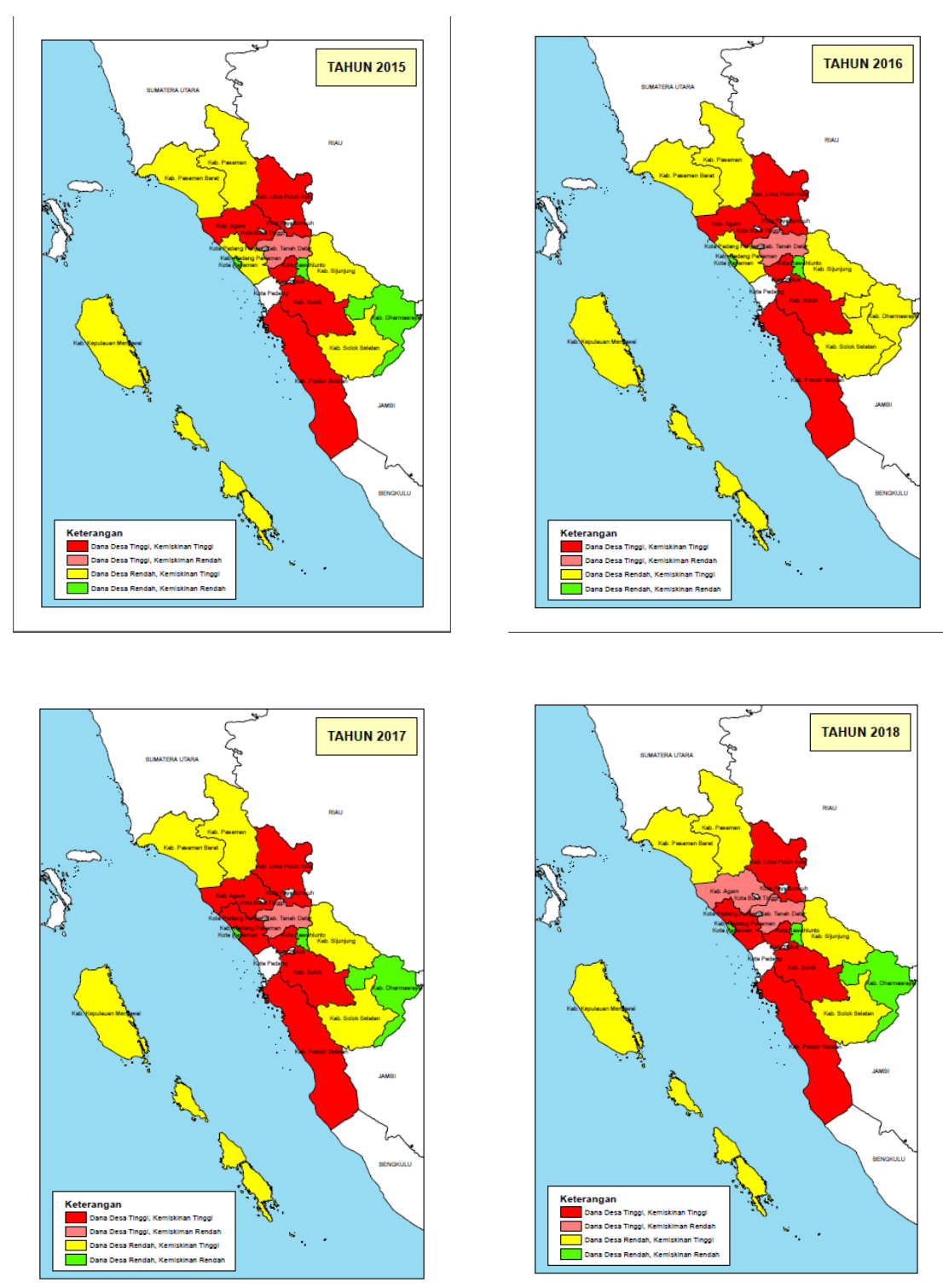

Gambar 2. Peta pengalokasian dana desa dan tingkat kemiskinan Kabupaten Kota di Sumatera Barat.

3.2 Dampak dana desa terhadap pertumbuhan ekonomi dan kemiskinan Sumatera Barat Hasil estimasi pada Tabel 1 menunjukkan dana desa berdampak negatif terhadap pertumbuhan ekonomi dan signifikan $(P>|t|=0,000)$. Nilai koefisien yang ditunjukkan hasil estimasi adalah -6.19e-14, ini berarti setiap penambahan 1 rupiah dana desa akan memperlambat pertumbuhan ekonomi sebesar 6.19e-14 persen. Kondisi ini dapat diartikan bahwa dana desa tidak memiliki dampak sebagaimana yang diharapkan dalam peningkatan pertumbuhan ekonomi di Sumatera Barat.

Hasil penelitian ini tidak sesuai dengan teori dan menunjukkan bahwa pengelolaan dana desa dilakukan kurang produktif untuk meningkatkan pertumbuhan ekonomi di Sumatera Barat. 
Namun Nurudeen dan Usman [13] juga menemukan bahwa beberapa variabel belanja pemerintah berdampak negatif terhadap pertumbuhan ekonomi di Nigeria. Pada penelitian tersebut ditemukan bahwa belanja modal pemerintah, belanja pendidikan, dan belanjabelanja pemerintah yang dialokasikan berulang-ulang membawa dampak negatif terhadap laju pertumbuhan ekonomi.

Untuk hasil estimasi terhadap kemiskinan yang terlihat pada Tabel 3, menunjukkan dana desa di Sumatera Barat berdampak negatif terhadap persentase kemiskinan dan signifikan $(P>|t|$ $=0,002$ ). Hal ini berarti ketika pemerintah meningkatkan anggaran dana desa maka akan dapat menurunkan kemiskinan. Menurut hasil estimasi setiap 1 rupiah dana desa dapat menurunkan tingkat kemiskinan sebesar 9,01e-14 persen. Kemampuan dana desa untuk menurunkan kemiskinan tersebut masih terbilang kecil. Namun, penelitian ini dapat menunjukkan bahwa kebijakan fiskal pemerintah ini dapat menjadi solusi dalam menurunkan kemiskinan di Sumatera Barat.

Selama periode penelitian, dana desa yang didistribusikan setiap tahunnya di Sumatera Barat bertambah walaupun tidak signifikan. Namun, dengan pengelolaan yang maksimal, penggunaan dana desa diharapkan dapat menunjang produktifitas, terutama di daerah perdesaan. Pembangunan perdesaan yang memperhatikan kondisi dan kearifan lokal akan lebih memberi kontribusi dalam meningkatkan pertumbuhan dan menurunkan kemiskinan. Fan et al [6] juga mengemukakan hal serupa, belanja pemerintah yang memperhatikan kebutuhan perdesaan, seperti jalan desa dan irigasi sangat signifikan mempengaruhi penurunan kemiskinan di perdesaan. Di samping itu, untuk memaksimalkan dampak belanja pemerintah menurut Nurudeen dan Usman [13] harus dipastikan jenis belanja yang diprioritaskan, jangan terdapat belanja berulang dan mendorong pendanaan lembaga anti korupsi.

Dalam penelitian lain oleh Anderson et al [14] pada beberapa negara sedang berkembang, tidak dapat dibuktikan bahwa pengeluaran pemerintah dapat membuat rumah tangga miskin menjadi lebih kaya atau paling tidak keluar dari kemiskinannya. Namun, kebijakan atas pengeluran pemerintah tersebut paling tidak dapat meningkatkan pendapatan keluarga miskin. Dorongan besar seperti yang disebut Nurkse [11] mungkin dapat dilihat pada kebijakan dana desa. Penanggulangan kemiskinan dapat diupayakan dengan menciptakan aktifitas pembangunan, aktifitas ekonomi, dan peningkatan kualitas sumber daya manusia perdesaan.

\subsection{Hasil estimasi variabel penjelas}

Pada variabel penjelas untuk model persamaan (I) yang ditunjukkan Tabel 1 , variabel pengangguran, rata-rata upah, dan angkatan kerja menunjukkan hubungan negatif terhadap pertumbuhan. Untuk ketiga variabel penjelas ini ditemukan hasil probabilitas tidak signifikan terhadap pertumbuhan. Kondisi ini menunjukkan bahwa peningkatan rata-rata upah karyawan atau buruh, pengangguran, dan angkatan kerja tidak berpotensi meningkatkan pertumbuhan ekonomi di Sumatera Barat pada kurun waktu penelitian. 
Dari hasil regresi model persamaan (II) yang ditunjukkan oleh Tabel 3, variabel pengangguran, rata-rata upah, dan angkatan kerja menunjukkan hubungan negatif terhadap persentase kemiskinan. Terdapat dua variabel penjelas di antaranya yang memiliki probabilitas yang signifikan terhadap variabel kemiskinan. Sedangkan variabel rata-rata upah tidak memiliki probabilitas yang signifikan $(P>|t|=0,226)$.

Jadi, terlihat kecenderungan bahwa peningkatan pengangguran membawa penurunan pada persentase kemiskinan, yang ditunjukkan signifikansi sebesar $P>|t|=0,002$ dengan koefisien beta sebesar $-0,1315$. Estimasi tersebut menunjukkan setiap peningkatan 1 persen tingkat pengangguran dapat menurunkan tingkat kemiskinan sebesar 0,1315 persen.

Begitupula dengan variabel angkatan kerja memiliki signifikansi $P>|t|=0,024$ dengan koefisien beta -1,95e-07. Estimasi ini menunjukkan bahwa peningkatan 1 orang angkatan kerja berpotensi menurunkan kemiskinan sebesar 1,95e-07 persen di Sumatera Barat. Sedangkan variabel rata-rata upah tidak terlihat memiliki hubungan yang signifikan terhadap variabel kemiskinan.

Hubungan yang tidak searah pada variabel pengangguran dengan kemiskinan ini tidak sesuai dengan teori yang ada. Fenomena ini menurut Yacoub [15] dapat disebabkan oleh adanya anggota keluarga lain yang memiliki pendapatan tinggi dan dapat menyokong anggota keluarga yang menganggur serta rendahnya jam kerja riil yang juga berakibat pada rendahnya produktifitas sehingga upah juga rendah. Ditambah lagi keharusan bagi keluarga miskin untuk tidak boleh menganggur dan keharusan memiliki penghasilan dalam memenuhi kebutuhan hidupnya. Pada periode penelitian, fenomena tersebut terlihat pada data pengangguran kabupaten kota di Sumatera Barat.

Sesuai data BPS [16] pada jangka waktu penelitian di Sumatera Barat, tingkat pengangguran daerah perkotaan rata-rata lebih tinggi dibandinglan perdesaan. Seperti terlihat pada tahun 2018 untuk kota penerima dana desa, yakni Kota Sawahlunto dan Kota Pariaman, tingkat penganggurannya adalah 5,75\% dan 5,72\%. Sedangkan untuk kabupaten tingkat penganggurannya terbilang lebih rendah seperti Kabupaten Kepulauan Mentawai yang hanya 2,27\% dan Kabupaten Lima Puluh Kota sebesar 2,70\%. Walaupun kecenderungan tingkat pengangguran perkotaan lebih tinggi, namun PDRB perkapita kota terlihat selalu lebih tinggi dibandingkan dengan kabupaten.

Sedangkan hasil estimasi yang diperoleh dari variabel angkatan kerja dengan kemiskinan sesuai dengan teori. Koefisien angkatan kerja yang diharapkan terhadap kemiskinan adalah negatif $(\beta<0)$. Antwi et al [7] mengemukakan bahwa angkatan kerja tidak berdampak positif terhadap pertumbuhan ekonomi dalam jangka pendek, namun berbeda hasilnya untuk jangka panjang. Hasil penelitian tersebut sesuai dengan temuan penelitian ini. Dimana sesuai hasil estimasi hubungan variabel angkatan kerja terhadap pertumbuhan adalah negatif. 
Berbeda dengan data pengangguran, sesuai data BPS [16] jumlah angkatan kerja kabupaten di Sumatera Barat terlihat lebih tinggi dibandingkan dengan kota. Namun, jumlah angkatan kerja terbanyak dimiliki oleh Kota Padang, sejalan dengan tingkat penganggurannya yang tertinggi. Pertumbuhan jumlah angkatan kerja ini juga seiring dengan pertambahan jumlah penduduk di masing-masing daerah di Sumatera Barat.

\section{Kesimpulan}

Hasil penelitian ini menunjukkan besar estimasi dampak penyaluran dana desa terhadap pertumbuhan dan kemiskinan di Sumatera Barat. Di mana dampak yang diharapkan masih terbilang kecil terhadap kemiskinan tapi mampu mengurangi kemiskinan. Sedangkan dalam meningkatkan pertumbuhan ekonomi terbilang kurang efektif. Penelitian ini juga memberi kejelasan bahwa kebijakan pemerintah terkait dana desa telah dapat menjadi salah satu motor penggerak penurunan tingkat kemiskinan di Kabupaten dan Kota Sumatera Barat. Pada jangka panjang diharapkan kebijakan dana desa dapat memberi dampak yang lebih baik dan memiliki efek ganda.

Pada penelitian ini juga digunakan pula variabel penjelas. Ketiga variabel penjelas tersebut adalah jumlah pengangguran, rata-rata upah, dan angkatan kerja yang terlihat memiliki dampak negatif terhadap pertumbuhan. Pada persamaan lainnya ditunjukkan pula hanya terdapat dua variabel penjelas yaitu jumlah pengangguran dan angkatan kerja, di samping variabel dana desa yang memiliki hubungan yang kuat terhadap kemiskinan dan berdampak negatif.

Akhirnya diperlukan kebijakan pembangunan yang berkelanjutan untuk dapat memberi dampak yang lebih besar terhadap tujuan pembangunan, terutama pembangunan yang dititikberatkan pada wilayah perdesaan. Pembangunan berbasis perdesaan dapat menjadi solusi persoalan ekonomi di Sumatera Barat serta upaya menciptakan tujuan bangsa dalam menciptakan pembangunan yang berkeadilan dan merata. Pembangunan yang berkeadilan ini akan meningkatkan pertumbuhan ekonomi dan menurunkan angka kemiskinan, terutama di daerah perdesaan. Di samping itu, dengan kebijakan pembangunan berbasis perdesaan diharapkan dapat menciptakan perdesaan yang mampu menopang wilayah perkotaan di sekitarnya.

\section{Referensi}

[1] Sjafrizal. Perencanaan Pembangunan Daerah Dalam Era Otonomi. Jakarta: Rajawali Pers; 2016.

[2] Van Der Ploeg JD, Renting H, Brunori G, Knickel K, Mannion J, Marsden T, et al. Rural development: From practices and policies towards theory. Sociol Ruralis 2000;40:391-408. https://doi.org/10.4324/9781315237213-11.

[3] Lewis BD. Mistakes, Decentralising to Villages in Indonesia: Money (and Other). Public Adm Dev 2015;35:347-59. https://doi.org/10.1002/pad.1741.

[4] Daforsa F, Handra H. Analysis of Village Fund Management in Poverty Alleviation at Pasaman Regency, West Sumatra. J Perspekt Pembiayaan Dan Pembang Drh 
2019;6:717-28. https://doi.org/10.22437/ppd.v6i6.6817.

[5] Tangkumahat FV, Panelewen VVJ, Mirah ADP. Dampak Program Dana Desa Terhadap Peningkatan Pembangunan Dan Ekonomi Di Kecamatan Pineleng Kabupaten Minahas. Agri - Sosio Ekon Unstrat 2017;13:335-42. https://doi.org/10.35791/agrsosek.13.2a.2017.17130.

[6] Fan S, Hazell P, Thorat S. Government Spending, Growth and Poverty in Rural India. Am J Agric Econ 2000;82:1038-51. https://doi.org/10.1111/0002-9092.00101.

[7] Antwi S, Mills EFEA, Zhao X. Impact of Macroeconomic Factors on Economic Growth in Ghana: A Cointegration Analysis. Int J Acad Res Accounting, Financ Manag Sci 2013;3:35-45.

[8] Kementerian Desa PDTT. Keputusan Menteri Desa PDTT Nomor 126 Tahun 2017 tentang Penetapan Desa Prioritas Sasaran Pembangunan Desa Pembangunan Daerah Tertinggal dan Transmigrasi 2017.

[9] Badan Pusat Statistik. Provinsi Sumatra Barat Dalam Angka 2018. Padang: BPS Provinsi Sumatera Barat; 2019.

[10] Oriavwote VE, Ukawe A. Government Expenditure and Poverty Reduction in Nigeria. J Econ Public Financ 2018;4:156-63. https://doi.org/10.22158/jepf.v4n2p156.

[11] Nurkse R. Problem Of Capital Formation In Underdeveloped Countries Chapter 7. Oxford: Basil Blackwell; 1953. https://doi.org/10.7135/UPO9781843318187.010.

[12] Badan Pusat Statistik. Data dan Informasi Kemiskinan Kabupaten/Kota Tahun 2018. Jakarta: Badan Pusat Statistik; 2019.

[13] Nurudeen A, Usman A. Government Expenditure And Economic Growth In Nigeria, 1970-2008: A Disaggregated Analysis. Bus Econ J 2010;1:1-11.

[14] Anderson E, D'Orey MAJ, Duvendack M, Esposito L. Does Government Spending Affect Income Poverty? A Meta-regression Analysis. World Dev 2018;103:60-71. https://doi.org/10.1016/j.worlddev.2017.10.006.

[15] Yacoub Y. Pengaruh Tingkat Pengangguran terhadap Tingkat Kemiskinan Kabupaten/Kota di Provinsi Kalimantan Barat. J Eksos 2012;8:176-85.

[16] Badan Pusat Statistik. Keadaan Angkatan Kerja di Provinsi Sumatera Barat Agustus 2020. Padang: Badan Pusat Statistik Provinsi Sumatera Barat; 2019. 